\title{
Lumen
}

Selected Proceedings from the Canadian Society for Eighteenth-Century Studies

\section{Revolution and Counter-Revolution in the Plays of M. G. Lewis}

\section{L. Macdonald}

Volume 14, 1995

URI : https://id.erudit.org/iderudit/1012515ar

DOI : https://doi.org/10.7202/1012515ar

Aller au sommaire du numéro

Éditeur(s)

Canadian Society for Eighteenth-Century Studies / Société canadienne d'étude du dix-huitième siècle

ISSN

1209-3696 (imprimé)

1927-8284 (numérique)

Découvrir la revue

Citer cet article

Macdonald, D. L. (1995). Revolution and Counter-Revolution in the Plays of M.

G. Lewis. Lumen, 14, 139-147. https://doi.org/10.7202/1012515ar d'utilisation que vous pouvez consulter en ligne.

https://apropos.erudit.org/fr/usagers/politique-dutilisation/ 


\section{Revolution and Counter-Revolution in the Plays of M. G. Lewis}

At the climax of The Castle Spectre (1797), Monk Lewis's first melodrama, Angela is trying to escape from her wicked uncle's castle through a secret passage. She loses her way, and finds herself in the 'gloomy subterraneous Dungeon' where her father, Reginald, the villain's older brother, has been imprisoned for sixteen years. ${ }^{1}$ There the villainous Osmond finds them. He threatens to murder Reginald unless Angela agrees to marry him; but, just as he is about to put his threat into effect, he is distracted by the apparition of the castle spectre, the ghost of Angela's mother, whom he murdered sixteen years before. Angela seizes the opportunity to stab him with the dagger with which he committed this crime, and which she has found, still bloodstained, earlier in the play. Then the hero arrives too late to be of much help, as is usual in Gothic melodrama - and the curtain falls.

The epilogue was spoken by Dorothy Jordan, who played Angela. Although many epilogues from the period are delivered in propria persona, this one is in character ('papa' and 'mama' clearly refer to Angela's parents, not to Jordan's). It is devoted to a justification of the unladylike act Angela has just been forced to commit:

No terrors awe my bosom, I'll assure ye;

Just is my cause, and English is my jury!

Besides, it must appear, on explanation,

How very ticklish was my situation,

And all perforce, his crimes when I relate,

Must own that Osmond well deserved his fate.

He heeded not papa's pathetic pleading;

He stabbed mama - which was extreme ill-breeding;

And at his feet for mercy when I sued,

The odious wretch, I vow, was downright rude.

Twice his bold hands my person dared to touch!

Twice in one day! — 'Twas really once too much!

And therefore justly filled with virtuous ire, 
To save my honour, and protect my sire,

I drew my knife, and in his bosom stuck it;

He fell, you clapped, and then he kicked the bucket ${ }^{2}$

At the climax of Adelgitha; or, The Fruits of a Single Error (1806), Lewis's second original tragedy, Adelgitha meets the villain, Michael Ducas, in a Gothic cavern. He has learned of her single error - she was seduced and abandoned in her youth, though she has since been happily and faithfully married for twelve years - and he has been attempting to use the secret to blackmail her into abandoning her husband and eloping with him. She has arranged the meeting in the hope of persuading him to spare her; he has agreed in order to lure her to a secluded spot from which he can abduct her without fear of interruption. When he refuses to spare her, she stabs him. As he sinks to the earth, he calls her a murderess. Her reaction is less nonchalant than Angela's:

\footnotetext{
Murderess? — Right! right! — 'tis now my fittest name!

Rise, daemons, rise! 'Tis Adelgitha calls you;

Her hand has signed in blood the infernal bond,

Which makes her yours for ever! Rise then, rise,

And shake the rocks with horrid mirth, loud shrieking

—“Rejoice! rejoice! the murderess is our own!" ${ }^{3}$
}

After an impressive mad scene, she confesses everything to her husband. He forgives her, and she kills herself in gratitude.

Angela's and Adelgitha's very different responses to their very similar acts suggest some of the differences between the two dramatic genres to which Lewis devoted most of his creative energy. Counting translations, adaptations, and re-adaptations, he wrote seven melodramas and five tragedies. His most famous work, though not a play, draws on both genres. The main plot of The Monk (1796) is tragic; indeed, Adelgitha's hysterical declaration that her 'hand has signed in blood [an] infernal bond' recalls the tragic climax of the novel, in which Ambrosio signs a pact with the Devil in the hope of escaping the Inquisition. The subplot of The Monk is melodramatic; indeed, it is largely borrowed from Les Victimes cloîtrées, by Jacques-Marie Boutet de Monvel, which has been described as the first melodrama, which Lewis probably saw in Paris in 1791, and which he later translated as Venoni; or, The Novice of St. Mark's (1809). ${ }^{4}$ The contrast between these two plots, like the contrast between the fates of Angela and Adelgitha, suggests that Gothic melodrama might be seen as generally revolutionary and Romantic tragedy as generally counter-revolutionary in tendency. ${ }^{5}$ The tragic main plot of The Monk ends with the damnation of the overreacher Ambrosio; the melo- 
dramatic subplot ends with the destruction of an oppressive institution, the convent of St. Clare, and the liberation of a captive, Agnes.

Lewis's contemporaries certainly saw the two genres in these terms. Looking back in 1841, Charles Nodier thought that melodrama had been essentially a revolutionary phenomenon:

This much is certain, that given the circumstances within which it appeared, the melodrama was necessary. The entire populace had enacted in the streets and public squares the greatest drama in history. Everyone had been an actor in this bloody play, everyone had been a soldier, or a revolutionary, or an exile. These solemn spectators, who had inhaled the scent of powder and blood, needed emotions analogous to those from which the return of order had severed them. They needed conspiracies, dungeons, scaffolds, battlefields, powder and blood; the unmerited misfortunes of the great and famous, the insidious maneuvers of the traitors, the perilous self-sacrifice of good men. ${ }^{6}$

In Britain, although audiences - especially lower-class audiences enjoyed Gothic melodrama, the élite, including the critics, tended to see it as subversive, as posing a threat to the legitimate drama in its form and to legitimate political institutions in its content. Coleridge denounced it as the "modern Jacobinical drama. ${ }^{7}$

Formally, the critics saw - and objected to - melodrama as an illegitimate mixing of genres rather than as a new genre in its own right. In 1791, the Critical Review described Francis North's The Kentish Barons as a 'Play' and imagined the author as saying to himself: 'I would have it both tragedy and comedy; and if it were a little farcical, so much the better: above all, if you could add a spice of the opera ..... ${ }^{8}$ In 1802 , the same journal dismissed Thomas Holcroft's A Tale of Mystery as 'a mixture of farce and pantomime. ${ }^{\prime 9}$

Lewis's melodramas met with much the same reception. The Monthly Magazine called The Castle Spectre a 'tragedy-pantomime'; the Monthly Review began its review by asking 'What do you call it? - a drama, it seems, it must be. ${ }^{10}$ Related objections were made to a scene requiring John Philip Kemble, the eminent tragedian who played the hero, to escape from the castle by jumping out a window: the Morning Herald (16 December 1797) and The Times (15 January 1798) complained that it made a harlequin out of him, and his biographer later sniffed: 'It is only in a barn that the CATO of a company should be allowed to risk his neck. ${ }^{11}$ A metropolitan actor should not be required to perform like a provincial acrobat. Lewis's later melodramas drew similar objections. Reviewing Adelmorn, the Outlaw (1801), the British Critic declared: 'we should be pleased to see this writer apply his talents to some more legitimate species of the drama'; the Critical Review wished 'he would attend half 
so much to classical study and chaste drama as he has unfortunately done to German absurdity. ${ }^{12}$

The plot of The Castle Spectre was as disturbing as its mixture of genres: it ends with an escape from a Bastille-like dungeon, and with the overthrow of the established authority figure, Earl Osmond. ${ }^{13}$ Moreover, it attacks the slave trade and lampoons the Church in the person of Father Philip, a gluttonous and lecherous, if basically good-natured, monk. Critics variously found it indecent, irreligious, or subversive. 'Youth courts the praise of wit,' pronounced the British Critic, 'and despises that of morality. The time will come when Mr. Lewis will wish to find some better distinction, than that of author of a work, which degrades him in the mind of every man who has one genuine feeling of morality or religion. ${ }^{14}$ The Monthly Visitor thought that the abolitionist passages were actually intended to defend uprisings like the Haitian revolution, to justify the blacks, in their execution of black gratitude, and black vengeance. $^{15}$

The Castle Spectre retained its reputation as a subversive play. Michael Kelly, who composed the music for it, included in his Reminiscences (1826) the ludicrous anecdote that Lewis had had it performed in Jamaica, for the entertainment of his slaves: 'they were delighted, but ... that which delighted them most was the character of Hassan, the black.' According to Kelly, they expressed their black gratitude by poisoning their master. ${ }^{16}$ (Lewis did not arrange for the staging of any of his plays in Jamaica, and he died, unpleasantly but apolitically, of yellow fever.)

Tragedy, by contrast, was in Lewis's hands a frankly counter-revolutionary genre. ${ }^{17}$ Both of his original tragedies, and one of his translations, contain obvious if pathetically unconvincing portraits of the 'patriotking' George III, ideal rulers who preside over the tragic action without being directly involved in it. The most extreme example is Adelgitha's husband Robert Guiscard, Prince of Apulia, the 'patriot prince,'

Who seeks no empire but his people's love;

Who fears no danger but his people's hate;

Who draws himself no glory from a throne,

But makes a throne seem glorious by his virtues. ${ }^{18}$

Each of these ideal rulers faces a revolutionary force. In Rolla; or, The Peruvian Hero (1799), a translation from Kotzebue, the upstart conquistador Pizarro invades Peru, much as the upstart Napoleon threatened to invade Britain. (In Pizarro, Sheridan's version of the same play, the parallel is made even more obvious.) In Alfonso, King of Castile (1801), the villain Caesario leads an uprising to avenge his father, whom Alfonso has unjustly imprisoned for treason; but the wronged father refuses to 
join it. 'What are my wrongs against a monarch's rights?' he asks, 'What is my curse against a nation's blessings? ${ }^{\prime 19}$ Caesario's uprising, like Pizarro's invasion, is defeated. Robert Guiscard is evidently too well-beloved a ruler ever to have to face a rebellion among his own subjects; instead, he puts down a rebellion against Michael Ducas, the emperor of Byzantium. Michael has clearly been a tyrant, but his tyranny is clearly no excuse for his subjects' rising against him, any more than his subsequent treachery, ingratitude, and lust are an excuse for Adelgitha's murdering him. A member of Guiscard's court asks rhetorically: 'Wronged were the Greeks?' and then answers herself conclusively, 'still Michael was their king. ${ }^{20}$ Jeffrey Cox has pointed out the parallels between Apulia's suppression of a revolution across the Adriatic and Britain's opposition to the Revolution across the Channel. ${ }^{21}$

The critical response to Lewis's tragedies was accordingly less hostile than to his melodramas. The Critical Review congratulated him on Alfonso and assured him that 'true fame consists in the approbation of the discerning few, not in the shouts of the vulgar., ${ }^{22}$ In the Edinburgh Review, Sydney Smith declared himself 'highly delighted' with the 'symptoms of returning, or perhaps nascent purity in the mind of Mr. Lewis. ${ }^{23}$ The Poetical Register praised both the form and the content of Adelgitha: "The interest which it excites is powerful, and is sustained to the very last scene; the characters are forcibly drawn, and both the language and versification are highly poetical. The moral, likewise, is unexceptionable. ${ }^{24}$ Not surprisingly, it was the unexceptionable Adelgitha, rather than The Castle Spectre, that appealed to Jamaican theatregoers. Lewis happened to see it performed in Kingston, on his second trip to the island, and he noted that the moral was enforced as emphatically as anybody could want: 'I may reckon it among my other misfortunes on this ill-starred expedition, that it was my destiny to sit out the tragedy of "Adelgitha," whom the author meant only to be killed in the last act, but whom the actors murdered in all five. ${ }^{25}$

When, after the comparative failure of Venoni, Lewis announced his intention of retiring as a dramatist, the Monthly Panorama drew an explicit contrast between his tragedies and his melodramas: 'The loss of the author of Alphonso, and of Adelgitha, we might regret, but we could very well spare the author of Venoni. ${ }^{26}$

Of course, the two authors were the same man, with the same social position and the same opinions; it would be a mistake to exaggerate the difference between them. In fact, he shared the conservative suspicion of Gothic politics. Recommending Godwin's Caleb Williams to his mother, he added regretfully that the author was 'half a Democrate. ${ }^{27}$ His own melodramas might be described as only half-democratic. As a result, though they were attacked by the critics, they made it past the 
censor, and found a place on the stages of theatres protected by a royal monopoly, even in the reactionary climate of wartime Britain. They were successful with the public, but not always more so than the tragedies. In any case, the public's mood was patriotic, not revolutionary.

The reason why Lewis's Angela can rely on an English jury is simple: her cause, by English standards, really is just. The revolutionary content of Lewis's melodramas is only apparent - only the top half is democratic. Cox argues that the genre 'finally is a conservative, even reactionary form, seeking the restitution of conventional order in the face of revolutionary change. ${ }^{28}$ Brooks is more explicit: the melodramatic plot ends with the restoration of an old society, not with the formation of a new one. ${ }^{29}$ Although Lewis's melodramas almost all end with the overthrow of established authority figures, the figures overthrown are always usurpers, and they are never overthrown by a popular uprising. The real Earl in The Castle Spectre is not Osmond, but his older brother Reginald, the captive. The hero, Percy, turns out to be the Earl of Northumberland, who has disguised himself as a peasant in order to win the love of Angela, the heroine, who has been raised as a peasant but turns out to be the daughter of Reginald: it is as though an aristocratic Revolution had overthrown Napoleon and released Louis XVI from the Bastille. In fact, in an unpublished poem entitled 'France and England in 1793,' Lewis describes Marie Antoinette, if not Louis, as just such a Gothic captive:

Now for awhile [Freedom] bends her loathing sight,

Where rear the Temple's walls their massy height,

Whose threatening horrors, scowling oër the scene,

Hold in their drear embrace a Captive Queen.

Amidst these glooms profound, these frowning Towers,

Sad Antoinette consumes the fearful hours,

And mourns the day, She left the Austrian climes,

To hear her thoughtless errors taxed as crimes.

Scorned as a Sovereign, Slandered as a Wife,

Almost debarred the coarse support of life,

Wasted with agony, with sickness weak,

On her fair hand She rests her faded cheek,

While her stern Jailors gaze with eyes of stone,

And taunting mock the tear, or chide the groan.

'Tis thus, sad victim of inveterate Foes,

She waits, yet shudders at, her final close;

And oft when steps approaching fright her ear,

Trembling She starts, and thinks the Murderer near.

Yet still unchanged, in grief still fond and mild, 
Doating She hangs oër either lovely Child, And murmurs, while her tears their cheeks bedew,

— "Dear Babes, my bitterest fears are felt for You!"30

In The Castle Spectre, the real, subordinate status of Osmond is revealed by what the epilogue calls the 'downright rude[ness]' and 'extreme ill-breeding' of his villainous behaviour. The authentic peasants in the play are all comic characters, and they are all passionately loyal to their superiors: unlike Osmond, they know their place. The play finally endorses the values that the Revolution tried to abolish.

The relation between the revolutionary appearance and the reactionary reality of Lewis's melodramas may be illustrated by the only one in which, as in his tragedies, the revolution is crushed, Rugantino; or, The Bravo of Venice (1805), which is based on Lewis's own translation of a novel by the Swiss counter-revolutionary propagandist Johann Heinrich Daniel Zschokke. The central character is a super-bandit, a master of disguise, who defies all the efforts of the Venetian authorities to identify or apprehend him. To make matters worse, he joins a conspiracy against the state - a conspiracy underwritten by a sinister foreigner identified only as 'The Emperor'. In the end, however, he turns out to have joined the conspiracy only in order to expose it; he is really the Prince of Milan, who has decided to save Venice partly out of princely good-neighbourliness and partly out of love for the Duke's daughter, Rosabella. His disguises enable him not only to infiltrate the conspiracy but also to test Rosabella's constancy: 'The perfidy of one ungrateful woman,' he explains, 'had made me distrust the whole sex; and I swore never to unite my fate but to her who would be constant to me under every circumstance,' and every change of appearance. ${ }^{31}$ The apparently subversive trickster is really a sexually reactionary figure (who would clearly be more comfortable with the punishment of Adelgitha than with the triumph of Angela) as well as a politically counter-revolutionary one. Terence Hoagwood has recently suggested that the political use of disguise' that is so frequent in dramas of the Romantic period may allude to, and would certainly have reminded English audiences of, the government's use of disguised agents provocateurs during such episodes as the 'Church and King' riots. ${ }^{32}$ One might also argue, more generally, that Lewis's melodrama itself, like Rugantino, puts on a revolutionary disguise for a counter-revolutionary purpose (and critics who denounced it were all part of the disguise): it appropriates for the cause of legitimacy the thrill of the illegitimate. 


\section{Notes}

1 Matthew Gregory Lewis, The Castle Spectre: A Drama (London: J. Bell, 1798) 88.

2 Lewis, The Castle Spectre v-vi.

3 Matthew Gregory Lewis, Adelgitha; or, The Fruits of a Single Error (London: J.F. Hughes, 1806) 94.

4 Peter Brooks, The Melodramatic Imagination: Balzac, Henry James, Melodrama, and the Mode of Excess (New Haven: Yale UP, 1976) 50; Louis F. Peck, A Life of Matthew G. Lewis (Cambridge, Mass.: Harvard UP, 1961) 187.

5 See Brooks, The Melodramatic Imagination 14-15.

6 Quoted in Jeffrey N. Cox, In the Shadows of Romance: Romantic Tragic Drama in Germany, England, and France (Athens: Ohio UP, 1987) 47.

7 Brooks, The Melodramatic Imagination xii, 89; Jeffrey N. Cox, ed. and introd., Seven Gothic Dramas (Athens: Ohio UP, 1992) 11; Samuel Taylor Coleridge, Biographia Literaria: Edited with his Aesthetical Essays, ed. J. Shawcross, 2 vol. (Oxford: Oxford UP, 1907) 2:192-93.

8 Review of The Kentish Barons, by Francis North, Critical Review 2nd series 2 (1791): 473.

9 Review of $A$ Tale of Mystery, by Thomas Holcroft, Critical Review 2nd series 36 (1802): 477.

10 Review of The Castle Spectre, by Matthew Gregory Lewis, Monthly Magazine Supp. 6 (1798): 515, and Monthly Review new series 26 (1798): 96.

11 Cox, Seven Gothic Dramas 24, 180n; James Boaden, Memoirs of the Life of John Philip Kemble, Esq., including a History of the Stage, from the Time of Garrick to the Present Period, 2 vol. (London: Longman, Hurst, Rees, Orme, Brown, and Green, 1825) 2:207.

12 Review of Adelmorn, the Outlaw, by Matthew Gregory Lewis, British Critic 18 (1801): 545, and Critical Review 2nd series 34 (1802): 232.

13 Cox, Seven Gothic Dramas 18-19.

14 Review of The Castle Spectre, by Matthew Gregory Lewis, British Critic 11 (1798): 436.

15 Review of The Castle Spectre, by Matthew Gregory Lewis, Monthly Visitor 3 (1798): 108.

16 Michael Kelly, Reminiscences of Michael Kelly, of the King's Theatre, and Theatre Royal Drury Lane, including a Period of Nearly Half a Century; with Original Anecdotes of Many Distinguished Persons, Political, Literary, and Musical, 2 vol. (London: Henry Colburn, 1826) 2:142.

17 See Cox, Seven Gothic Dramas 46-49.

18 Lewis, Adelgitha 81, 37.

19 Matthew Gregory Lewis, Alfonso, King of Castile (London: J. Bell, 1801) 62.

20 Lewis, Adelgitha 3.

21 Cox, Seven Gothic Dramas 49-50. 
22 Review of Alfonso, King of Castile, by Matthew Gregory Lewis, Critical Review 2nd series 34 (1802): 355.

23 [Sydney Smith], review of Alfonso, King of Castile, by Matthew Gregory Lewis, Edinburgh Review 1 (1802-03): 314.

24 Review of Adelgitha, by Matthew Gregory Lewis, Poetical Register 6 (1806): 527.

25 Matthew Gregory Lewis, Journal of a West India Proprietor, Kept during a Residence in the Island of Jamaica (London: John Murray, 1834) 363-64.

26 Review of Venoni, by Matthew Gregory Lewis, Monthly Panorama 1 (1810): 126.

27 Quoted in Peck, A Life of Matthew G. Lewis 213.

28 Cox, Seven Gothic Dramas 41.

29 Brooks, The Melodramatic Imagination 32.

30 Matthew Gregory Lewis, 'France and England in 1793.' Ms. 114 p. 386, National Library of Jamaica, Kingston. Courtesy of the National Library of Jamaica.

31 Matthew Gregory Lewis, Rugantino: or, The Bravo of Venice (London: J.F. Hughes, 1805) 3, 54.

32 Terence Allan Hoagwood, 'Prolegomenon for a Theory of Romantic Drama,' Wordsworth Circle 23 (1992): 55-56. 